\title{
PRODUCTION OF CUCUMBER SEEDLINGS IN ALTERNATIVE SUBSTRATES WITH DIFFERENT COMPOSITIONS OF AGRICULTURAL RESIDUES ${ }^{1}$
}

\author{
LOUISE PINTO GUISOLFI ${ }^{2 *}$, PAOLA ALFONSA VIEIRA LO MONACO ${ }^{3}$, ISMAIL RAMALHO HADDADE ${ }^{3}$, \\ MARCELO RODRIGO KRAUSE ${ }^{2}$, LORENA APARECIDA MERLO MENEGHELLI ${ }^{2}$, KAROLINE MATIELLO \\ ALMEIDA $^{2}$
}

\begin{abstract}
Studies on the use of agricultural residues as an alternative to commercial substrates have become fundamental tominimising the risk of environmental contamination resulting from inadequate disposal, as well as reducing seedling production costs. This research involved an evaluation of growth variables and quality of cucumber seedlings produced in substrates with different compositions of agricultural waste with a view to providing substitutes for commercial substrate. The experiment was based on a completely randomised design, with six treatments and ten replicates. There were five treatments with increasing proportions of moinha/decreasing proportions of carbonized rice husk (0/40,10/30, 20/20,30/10 and 40/0\%) and fixed proportions of coconut fibre (15\%), eggshell (5\%), pine bark (40\%), and one commercial substrate treatment as the control (Bioplant $\left.{ }^{\circledR}\right)$. The variables evaluated were: electrical conductivity of the substrate, plant height, stem diameter, number of leaves, Dickson quality index (DQI) and dry matter of roots and above ground parts. Results show that alternative substrates can replace commercial substrate without impairing the quality of cucumber seedlings. However, the substrate containing $40 \%$ of moinha, $0 \%$ of rice husk, $15 \%$ of coconut fibre, $5 \%$ of eggshell and $40 \%$ of pine bark resulted in the highest values for all evaluated variables and appears to be the most promising alternative substrate for the production of cucumber seedlings.
\end{abstract}

Keywords: Cucumis sativus L.. Horticulture. Organic substrates.

\section{PRODUÇÃO DE MUDAS DE PEPINO EM SUBSTRATOS ALTERNATIVOS COM DIFERENTES COMPOSIÇÕES DE RESÍDUOS AGRÍCOLAS}

RESUMO - Estudos relacionados ao aproveitamento de resíduos agrícolas como substratos alternativos aos comerciais tornaram-se fundamentais por minimizar o risco de contaminação ambiental decorrente do descarte inadequado, além de diminuir os custos de produção de mudas. Assim, objetivou-se avaliar as variáveis de crescimento e a qualidade de mudas de pepino produzidas em substratos com diferentes composições de resíduos agrícolas, em substituição total ao substrato comercial. O experimento foi realizado no delineamento inteiramente casualizado, com seis tratamentos e dez repetições, sendo cinco tratamentos com proporções crescentes de moinha/decrescentes de casca de arroz $(0 / 40 ; 10 / 30 ; 20 / 20 ; 30 / 10$ e 40/0\%) e proporções fixas de fibra de coco (15\%), casca de ovo (5\%) e casca de pinus $(40 \%)$, e um tratamento controle com substrato comercial (Bioplant $(\mathbb{R})$. As variáveis avaliadas foram: condutividade elétrica do substrato, altura da planta, diâmetro do colo, número de folhas, Índice de Qualidade de Dickson (IQD) e massas secas da raiz e da parte aérea. Os substratos alternativos podem substituir o substrato comercial, sem que haja prejuízos à qualidade de mudas de pepino. Entretanto, o substrato contendo 40\% de moinha, 0\% de casca de arroz, 15\% de fibra de coco, $5 \%$ de casca de ovo e $40 \%$ de casca de pinus proporciona os maiores valores para todas as variáveis avaliadas, sendo o mais indicado na produção de mudas de pepino.

Palavras-chave: Cucumis sativus L.. Olericultura. Substratos orgânicos.

\footnotetext{
${ }^{*}$ Corresponding author

${ }^{1}$ Received for publication in 03/06/2017; accepted in 09/08/2017.

Paper extracted from the completion of course work of the first author.

${ }^{2}$ Department of Plant Science, Universidade Federal Viçosa, Viçosa, MG, Brazil; louisepguisolfi@gmail.com - ORCID: 0000-0002-79232562, agro.krause@gmail.com - ORCID: 0000-0002-7035-9030, lorena.merlo@hotmail.com - ORCID: 0000-0002-7043-4838, karolinematiello@hotmail.com - ORCID: 0000-0001-6691-9042.

${ }^{3}$ Department of Agronomy, Instituto Federal do Espírito Santo, Santa Teresa, ES, Brazil; paolalm@ifes.edu.br - ORCID: 0000-0001-54987451, ihaddade@gmail.com - ORCID: 0000-0003-0303-8808.
} 


\section{INTRODUCTION}

In recent years, cucumber (Cucumis sativus) has become one of the fruit vegetables attracting the greatest commercial interest in Brazil. In addition to its economic and food value, cucumber cultivation also has great social importance, namely the direct and indirect generation of jobs, since it requires a large amount of labor, from cultivation to commercialisation (FILGUEIRA, 2008).

Within the production chain of fruit and vegetables, a decisive factor for obtaining quality seedlings is the type of substrate used. The substrate must provide adequate air and water supply to the root system (SANTOS JÚNIOR et al., 2014), as well as providing sufficient nutrient content and good cation exchange capacity (OLIVEIRA; HERNANDEZ; ASSIS JÚNIOR, 2008), and being easy to handle, of low cost and of high availability (KRAUSE et al., 2017).

In the production of cucumber seedlings, commercial substrates are widely used. However, these substrates represent an additional cost in the production stage of seedlings. According to Silva et al. (2014), as most plant cultivation in Brazil is carried out on a small scale by family farmers, the cost of substrates leads to decreased profitability of the investment, prompting the need to seek new alternative sources of substrate.

For this reason, many studies have investigated the use of agricultural residues in the composition of substrates for seedling production. In addition to reducing costs, this is a means of minimising the environmental impact caused by improper disposal of these wastes.

Among the residues generated in large quantities in the Espírito Santo State, with potential for use in alternative substrates for the production of cucumber seedlings, are pine bark, coconut fibre, charred rice husk, egg shell and the residue generated during the drying stage of the coffee beans, known as "moinha".

Properties, such as ease of drainage with pinus bark (MARTIN et al., 2008), high aeration space of rice husk (SAIDELLES et al., 2009), adequate water retention with fibre environment (ZORZETO et al., 2014), high amount of calcium available in eggshell (NAVES et al., 2007) and fertiliser potential, especially of nitrogen present in the moinha (MENEGHELLI et al., 2016), indicate that residues could represent alternative components to commercial substrates.

In formulating a substrate composed of these residues, it is fundamental to obtain the ideal proportion of moinha and rice husk suitable for the production of cucumber seedlings. As rice husks are predominantly produced in southern Brazil, their use can be costly because of high transportation costs. In contrast, moinha has high availability in the central region of Espírito Santo, well-known for the production of coffee and vegetables, making its use as a substitute for rice husk sustainable, beside reducing costs of the production stage of seedlings.

The objective of this study was to evaluate the growth and quality of cucumber seedlings produced in substrates containing different compositions of agricultural residues, with a view tocomplete substitution for commercial substrates.

\section{MATERIAL AND METHODS}

The experiment was carried out at the seedling nursery of the Instituto Federal do Espírito Santo - Campus Santa Teresa, in Santa Teresa County, Espírito Santo state. The nursery where the study was conducted was covered with an overflow screen, which reduced solar radiation by $50 \%$. The climate, according to the Köppen classification, is in the Cwa type (subtropical of dry winter) with temperatures and relative humidities of air outside the nursery varying from $19.9{ }^{\circ} \mathrm{C}$ to $38.2{ }^{\circ} \mathrm{C}$ and $47.5 \%$ to $69.5 \%$, respectively, during the experimental period.

The residues used in the alternative substrate for cucumber seedling production were coffee moinha (coffee drying residue), pine bark, egg shell, coconut fibre and charred rice husk. The eggshell was collected from local restaurants and subjected to drying in the sun, followed by grinding. The bark of charred rice and coconut fibre were donated by Empresa Fibria, located in Aracruz-ES. The pine bark was donated by the Demunner coffee seedling nursery, located in São Roque do Canaã - ES. The moinha was collected from farms located in Santa Teresa - ES. Before use, the moinha was sieved through a stainless steel sieve (4 $\mathrm{mm}$ mesh).

The chemical and physicochemical characterisation of the residues was carried out at the Laboratory of Soils and Solid Residues of the Agricultural Engineering Department, Universidade Federal de Viçosa, Minas Gerais state. The analysis consisted of determination of the $\mathrm{pH}$ in water, using a benchtop $\mathrm{pH}$ meter, and electrical conductivity, using a benchtop conductivity meter, and quantification of concentrations of total nitrogen (NT), phosphorus (P) and potassium (K), according to the methodology described by Matos (2015).

Table 1 presents the physical (EC) and chemical attributes of the commercial substrate and the different residues used in the composition of the substrates. 
Table 1. Physical (EC) and chemical attributes of the commercial substrate and the different residues used in the composition of the substrates.

\begin{tabular}{llllll}
\hline \multicolumn{1}{c}{ Residues } & $\mathrm{pH}$ & $\mathrm{EC}$ & $\mathrm{N}$ & $\mathrm{P}$ & $\mathrm{K}$ \\
& $\mathrm{dS} \mathrm{m^{-1 }}$ & \multicolumn{2}{c}{---------dag kg } & \\
\hline Commercial substrate & 5.62 & 0.99 & 0.62 & 1.550 & 0.44 \\
Egg shell & 9.37 & 0.37 & 0.87 & 0.084 & 0.06 \\
Coconut fibre & 7.15 & 0.09 & 0.66 & 0.053 & 0.14 \\
Moinha & 5.6 & 6.49 & 3.70 & 0.140 & 0.71 \\
Rice husk & 5.9 & 1.15 & 0.59 & 0.082 & 0.033 \\
Pine bark & 5.5 & 0.00113 & 0.40 & 0.102 & 0.17 \\
\hline
\end{tabular}

Cucumber seeds (Caipira variety) were sown in Styrofoam trays with 200 cells, placing one seed per cell.

The experiment was carried out using a completely randomised design, with six treatments and ten replicates. One treatment (T1) used commercial substrate as the control (Bioplant $\left.{ }^{\circledR}\right)$ and five treatments (T2 to $\mathrm{T} 6$ ) used increasing proportions of moinha /decreasing rice husk $(0 / 40$; $10 / 30 ; 20 / 20 ; 30 / 10$ and $40 / 0 \%$ by volume) and fixed proportions of coconut fibre $(15 \%)$, egg shell $(5 \%)$ and pinus bark (40\%), as described in Table 2. Each experimental unit consisted of 20 seedlings, totaling 1200 seedlings in the whole experiment. Six useful plants were considered for each experimental unit.

Table 2. Description of the treatments (T2 to T6) with the different proportions (by volume) of agricultural residues in the substrate.

\begin{tabular}{lrrrrr}
\hline \multirow{2}{*}{ Residues } & \multicolumn{5}{c}{ Proportions (\%) } \\
\cline { 2 - 6 } & T2 & T3 & T4 & T5 & T6 \\
\hline Moinha & 0 & 10 & 20 & 30 & 40 \\
Rice husks & 40 & 30 & 20 & 10 & 0 \\
Coconut fibre & 15 & 15 & 15 & 15 & 15 \\
Egg shell & 5 & 5 & 5 & 5 & 5 \\
Pine bark & 40 & 40 & 40 & 40 & 40 \\
\hline
\end{tabular}

The seedling production system involved suspended trays which were placed on concrete benches and hand-irrigated twice a day, in the morning and in the afternoon. No fertilizers were applied.

The evaluations took place at 24 days after sowing (DAS), in December, and consisted of measurement of seedling height and stem diameter, counting the number of leaves per seedling, determining the Dickson Quality Index (DQI) and quantification of the dry matter content of above ground parts and roots of the plant.

A millimeter-scale ruler was used to obtain the height of the aboveground parts, measuring from the base of the stem to the apical bud that gave rise to the last leaf. The stem diameter was measured using a precision digital caliper. Determination of the dry matter content of the above ground part and the roots involved cutting the plant close to the substrate and carefully washing the roots in running water in a sieve. The aboveground part and the roots were packed in paper bags and placed in an oven with forced air circulation at $65^{\circ} \mathrm{C}$ for 72 hours. The material was then weight using a precision electronic scale $(0.01 \mathrm{~g})$. The DQI was determined as a function of seedling height $(\mathrm{PH})$, stem diameter (SD), dry matter of the above ground part (DMAP) and the root system (DMR), using Equation 1, as proposed by Dickson, Leaf and Hosner (1960).

$$
\mathrm{DQI}=\frac{\mathrm{TDM}(\mathrm{g})}{\left(\frac{\mathrm{PH}(\mathrm{cm})}{\mathrm{SD}(\mathrm{mm})}\right)+\left(\frac{\mathrm{DMAP}(\mathrm{g})}{\operatorname{DMR}(\mathrm{g})}\right)}
$$

Equation (1)

Where DQI = Dickson's Quality Index, $\mathrm{TDM}=$ total dry matter $(\mathrm{g}), \mathrm{H}=$ plant height $(\mathrm{cm})$, $\mathrm{SD}=$ stem diameter $(\mathrm{mm}), \mathrm{DMAP}=$ dry matter of above ground part $(\mathrm{g})$ and DMR $=$ dry matter of root (g).

In addition to the biometric and gravimetric analyses, the electrical conductivity of the substrates was determined using a conductivity meter, following the methodology of Matos (2015).

All the evaluated variables were submitted to normality (Lilliefors), additivity (Tukey) and homoscedasticity (Bartlett) tests, necessary for the validation of their analysis of variance. Due to the qualitative difference between the commercial substrate (T1) and other treatments (T2 to T6), analysis of procedural variance for qualitative treatments was performed considering, in the decomposition of the sum of squares of the treatments, only the contrast between $\mathrm{T} 1$ and the other treatments. In addition, for comparisons between treatments $\mathrm{T} 2, \mathrm{~T} 3, \mathrm{~T} 4, \mathrm{~T} 5$ and $\mathrm{T} 6$ in relation to the moinha level, adjustments were adopted in regression models using the orthogonal polynomials method. A " $\alpha$ " of 0.05 was used for all procedures.

All statistical analyzes were performed using the Statistical Analysis Program, version 9.1. (SAEG, 2007). 


\section{RESULTS AND DISCUSSION}

For all variables analysed, no significant differences $(P>0.05)$ were observed between the control treatment (commercial substrate) and the groups with increasing levels of moinha and decreasing levels of rice husks, as can be seen in Table 3. Such results, especially those obtained for DQI, show that treatments with alternative substrates can replace commercial treatment without impairing the quality of cucumber seedlings. Among the alternative treatments, the use of the substrate containing the highest proportion of moinha and lowest rice husk content (40:0\%) becomes the most promising substitute for the commercial substrate, due to the greater availability of moinha in the central mountain region of Espírito Santo state, in addition to the low acquisition cost.

Table 3. Coefficients, significance levels and estimation of the contrasts between commercial substrate treatment (CS) and substrates containing increasing levels of moinha and decreasing rice husks

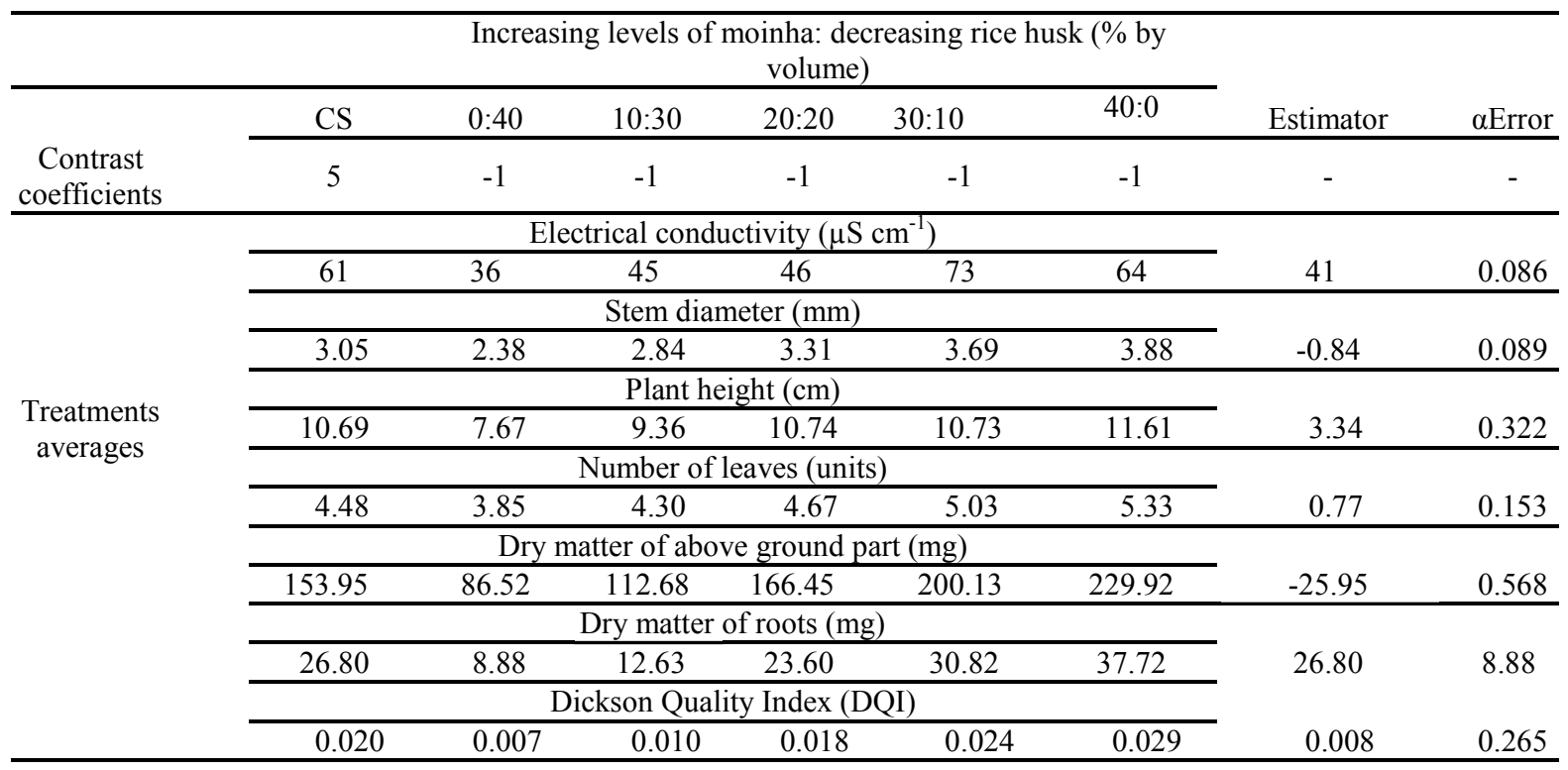

When evaluating the different levels of moinha (polynomial regression), first-order effects $(P<0.05)$ were observed for all variables analysed. Figures 1a, 1b, 1c, 1d, 1e, 1f and $1 \mathrm{~g}$ show the electrical conductivity (EC) of the substrate, plant height (PH), stem diameter (SD), number of leaves (NL), dry matter of above part (DMAP), dry matter of the roots (DMR) and Dickson Quality Index (DQI), respectively, as a function of increasing levels of moinha replacing the charred rice husk, in the composition of the substrates.

Results in Figure 1a show that, in general, increased moinha content of the substrate was associated with increased EC values, with $40 \%$ moinha giving the highest value $\left(69.6 \mu \mathrm{Scm}^{-1}\right)$. This result was not unexpected as moinha residue was associated with a high EC value (Table 1). Nevertheless, when mixed with other residues, it did not reach values that could adversely affect seedling development. Cavins et al. (2000) classified EC as very low $\left(0\right.$ to $\left.0.25 \mathrm{dS} \mathrm{m}^{-1}\right)$, low $(0.26$ to $\left.0.75 \mathrm{dS} \mathrm{m}^{-1}\right)$, normal $\left(0.76\right.$ to $\left.1.25 \mathrm{dS} \mathrm{m}^{-1}\right)$, high (1.26 to $1.75 \mathrm{dSm}^{-1}$ ), very high (1.76 to $2.25 \mathrm{dS} \mathrm{m}^{-1}$ ) and extreme (above $2.25 \mathrm{dS} \mathrm{m}^{-1}$ ). In this case, the value reported in this study $\left(0.07 \mathrm{dS} \mathrm{m}^{-1}\right)$ is within the very low range.

Figure $1 \mathrm{~b}$ shows that $40 \%$ moinha (and 0\% rice husks) produced the highest value for $\mathrm{PH}$ (11.86 $\mathrm{cm}$ ) of the different moinha levels used in the substrate. This result was superior to that reported by Cerqueira et al. (2015); substrates composed of humus, carbonized rice husks and commercial substrate in different containers did not produce cucumber seedling heights greater than $3.5 \mathrm{~cm}$. It should be noted that these authors evaluated the seedlings at 19 DAS (days after sowing), a shorter period than used in this study (24 DAS).

According to Figure 1c, $40 \%$ moinha in the substrate produced the largest stem diameter (3.97 $\mathrm{mm}$ ) in cucumber seedlings, while the lowest value $(2.45 \mathrm{~mm})$ was obtained with the substrate containing $0 \%$ moinha. Cerqueira et al. (2015) found no $\mathrm{SD}$ values greater than $2.6 \mathrm{~mm}$ in cucumber seedlings at 19 DAS, produced on substrates composed of humus and charred rice husk. 
a)

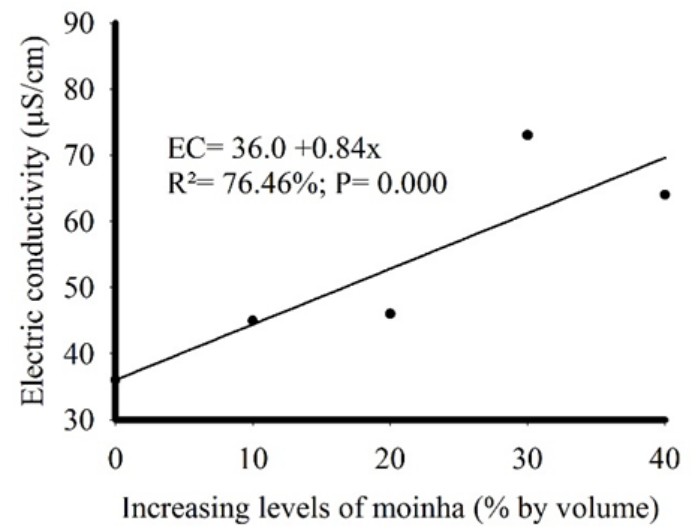

c)

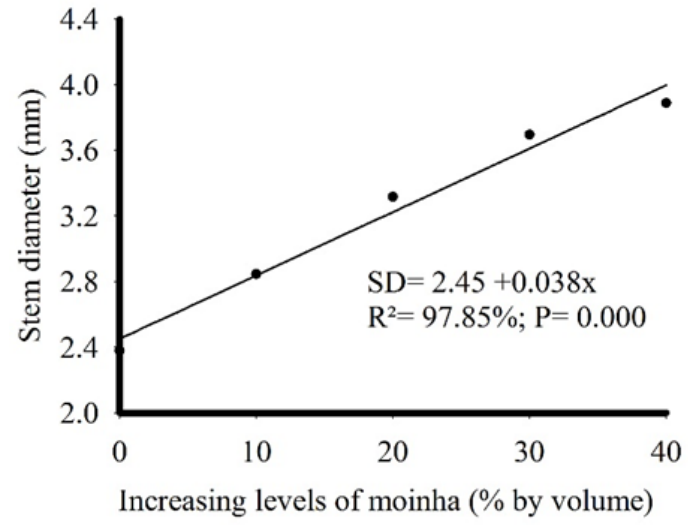

e)

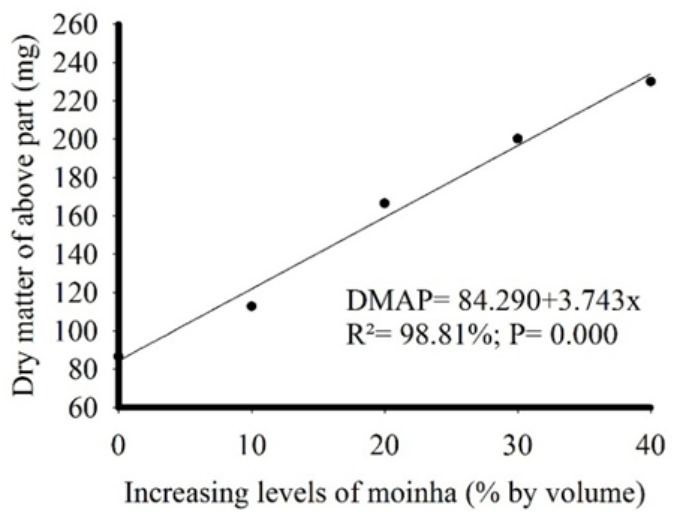

Increasing levels of moinha (\% by volume) b)

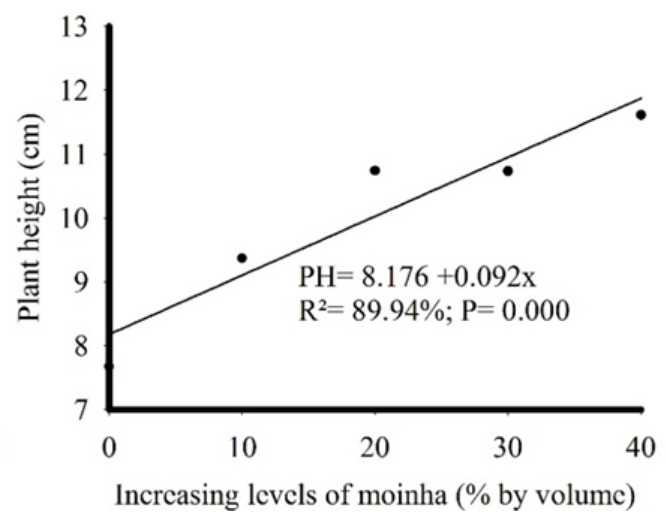

d)

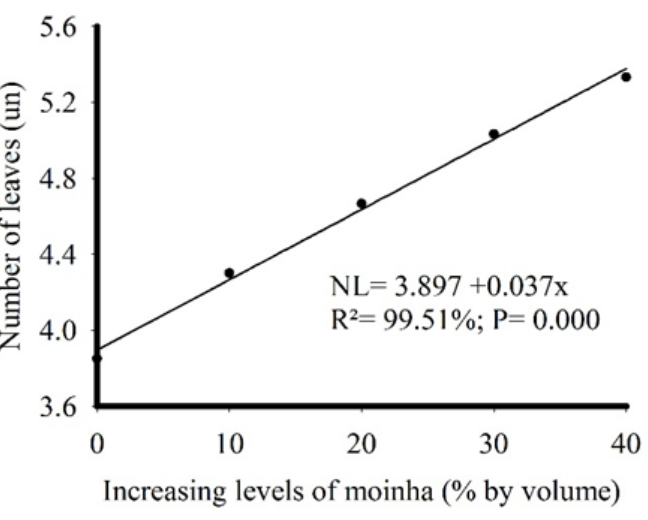

f)

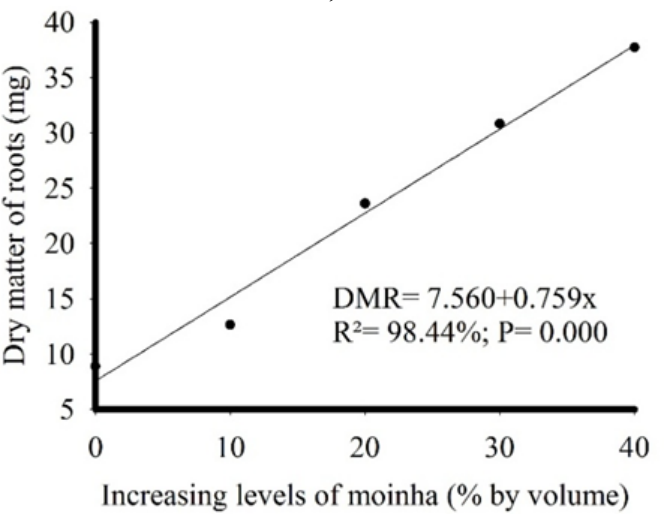

g)

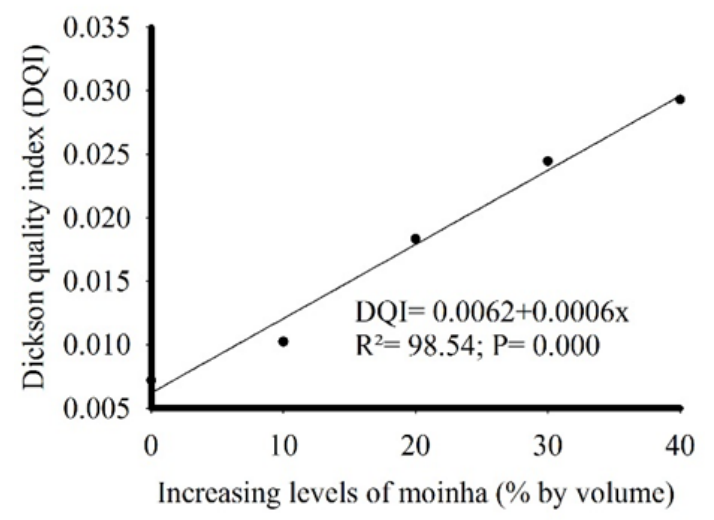

Figure 1. Electrical conductivity of the substrate (a), plant height (b), stem diameter (c), number of leaves (d), dry matter of above ground parts (e), dry matter of roots (f), and Dickson Quality Index (g) as a function of increasing levels of moinha in the substitution of charred rice husk in substrate composition. 
According to Figure 1d, 40\% moinha in the substrate produced the highest value for the number of leaves (5.38 units), while the lowest value was obtained in the substrate containing $0 \%$ moinha (3.90 units). However, the lower value obtained here, due to the absence of moinha, was higher than the results obtained by Silva et al. (2014) in cv. Caipira cucumber seedlings grown in substrates based on sheep manure, where, at $43 \mathrm{DAS}$, the number of leaves ranged from 1.63 to 1.98 units.

Formation of a good above ground part of the plant is extremely important in situations which provide limited space for growth of seedling roots, such as tubes or trays, due to the small volume of substrate in these containers (FERNANDES et al., 2008). In this way, it can be seen from Figure 1e that a proportion of $40 \%$ moinha in the substrate generated the highest value for the production of DMAP (234.01 $\mathrm{mg}$ ), while the lowest value was obtained in the substrate containing $0 \%$ moinha $(84.29 \mathrm{mg})$. These results are far beyond those obtained in the study of Lima et al. (2007), Costa et al. (2013) and Silva et al. (2014). Lima et al. (2007) reported values of DMAP between 16.83 and $19.63 \mathrm{mg}$ in cucumber seedlings grown in substrates with vermiculite and decomposed residue. Costa et al. (2013) reported 38 to $56 \mathrm{mg}$ DMAP at 20 DAS in cucumber seedlings grown in substrates formulated with composite and sand. Silva et al. (2014) reported DMAP values ranging from 125 to $242 \mathrm{mg}$ in cv. Caipira at 43 DAS, produced on substrates based on sheep manure and soil.

According to Souza et al. (2013), the formation of larger roots allows the seedlings to better exploit the volume of substrate available, allowing greater absorption of water and nutrients. In relation to this, results shown in Figure $1 \mathrm{f}$ demonstrate that, of the different moinha levels in the substrate investigated, $40 \%$ produced the highest value for DMR (37.92 mg), while the lowest value (7.56 mg) was obtained with substrate containing $0 \%$ moinha. Silva et al. (2014) obtained a maximum value of $210 \mathrm{mg}$ for root dry matter in cucumber seedlings at 43 DAS, using sheep manure and soil in a ratio of $1: 1$.

According to Marana et al. (2008), to avoid distortions resulting from excess nitrogen, for example, or from leaf growth at the detriment of the root system, quality indexes are used which represent the relationships between growth parameters. The Dickson Quality Index (DQI) is one of the most widely used index for evaluating the quality of seedlings, taking into account dry matter production of the above part, the roots and total dry matter, the height and the stem diameter of the plants (DICKSON; LEAF; HOSNER, 1960). The higher the index value, the higher the quality standard of the seedlings. According to Figure 1g, it was observed that the increase of the moinha in the substrate, with decreasing rice husk, produced increasing values of
DQI with cucumber seedlings, reaching the highest value $(0.0302)$ when $40 \%$ moinha and $0 \%$ rice husk was used.

In general, the substrate containing the highest proportion of moinha, replacing charred rice husk, $(40 \%$ moinha $+0 \%$ rice husk $+15 \%$ coconut fibre $+5 \%$ egg shell $+40 \%$ pine bark) resulted in the best plant development and the highest quality of cucumber seedlings. This result may be associated with the greater amount of nutrients, notably nitrogen, present in the substrate (Table 1). According to Oliveira et al. (2010), nitrogen plays an important role in plant metabolism and nutrition, and its deficiency causes nutritional disorders. In the case of cucurbits, the increase in nitrogen concentration, up to a certain limit, results in increased leaf area of the plant and, therefore, has an effect on photoassimilate production and, as a consequence, fruit production (QUEIROGA et al., 2007). Charred rice husk is a residue with less availability of nutrients compared to moinha (Table 1). This fact corroborates the lower values obtained for growth variables in this study when using substrates with higher proportions of rice husk and lower proportions of moinha.

\section{CONCLUSIONS}

Results of this study show that alternative substrates can replace commercial substrates without impairing the quality of cucumber seedlings. The substrate containing $40 \% \mathrm{MO}+0 \%$ rice husk $+15 \%$ coconut fibre $+5 \%$ eggshell $+40 \%$ pine bark produced the highest values for all variables evaluated in this study and is the most promising alternative substrate for the production of cucumber seedlings.

\section{REFERENCES}

CAVINS, T. J. et al. Monitoring and managing $\mathrm{pH}$ and EC using the Pour Thru Extraction Method. Horticulture Information Leaflet, Raleigh, v. 7, n. 590, p. 1-17, 2000.

CERQUEIRA, F. B. et al. Substratos e recipientes no desenvolvimento de mudas de pepino em alta temperatura. Global Science and Technology, Rio Verde, v. 8, n. 2, p. 61-73, 2015.

COSTA, L. A. M. et al. Avaliação de substratos para a produção de mudas de tomate e pepino. Revista Ceres, Viçosa, v. 60, n. 5, p. 675-682, 2013.

DICKSON, A.; LEAF, A. L.; HOSNER, J. F. Quality appraisal of white spruce and white pine seedling stock in nurseries. The Forestry 
Chronicle, Canada, v. 36, n. 1, p. 10-13, 1960.

FERNANDES, M. B. et al. Produção de mudas de pimentão e alface em diferentes combinações de substrato. Revista Verde de Agroecologia e Desenvolvimento Sustentável, Pombal, v. 3, n. 1, p. 133-137, 2008.

FILGUEIRA, F. A. R. Novo manual de olericultura: agrotecnologia moderna na produção e comercialização de hortaliças. 3. ed. Viçosa, MG: UFV, 2008. $421 \mathrm{p}$.

KRAUSE, M. R. et al. Aproveitamento de resíduos agrícolas na composição de substratos para produção de mudas de tomateiro. Horticultura Brasileira, Brasília, v. 35, n. 2, p. 293-298, 2017.

LIMA, J. D. et al. Resíduos da agroindústria de chá preto como substrato para produção de mudas de hortaliças. Ciência Rural, Santa Maria, v. 37, n. 6, p. 1609-1613, 2007.

MARANA, J. P. et al. Índices de qualidade e crescimento de mudas de café produzidas em tubetes. Ciência Rural, Santa Maria, v. 38, n. 1, p. 39-45, 2008.

MARTIN, T. N. et al. Utilização de vermiculita, casca de pínus e carvão na produção de mudas de pepino e de pimentão. Acta Scientiarum. Agronomy, Maringá, v. 28, n. 1, p. 107-113, 2008.

MATOS, A. T. Manual de análise de resíduos sólidos e águas residuárias. 1. ed. Viçosa, MG: UFV, 2015. 149 p.

MENEGHELLI, C. M. et al. Resíduo da secagem dos grãos de café como substrato alternativo em mudas de café Conilon. Coffee Science, Lavras, v. 11, n. 3, p. 330-335, 2016.

NAVES, M. M. V. et al. Avaliação microbiológica do pó da casca de ovo e otimização da técnica de elaboração do produto. Pesquisa Agropecuária Tropical, Goiânia, v. 37, n. 2, p. 113-118, 2007.

OLIVEIRA, A. B.; HERNANDEZ, F. F. F.; ASSIS JÚNIOR, R. N. Pó de coco verde, uma alternativa de substrato na produção de mudas de berinjela. Revista Ciência Agronômica, Fortaleza, v. 39, n. 1, p. 39-44, 2008.

OLIVEIRA, F. D. A. et al. Interação entre salinidade e fontes de nitrogênio no desenvolvimento inicial da cultura do girassol. Brazilian Journal of Agricultural Sciences/Revista Brasileira de Ciências Agrárias, Recife, v. 5, n. 4, p. 479-484, 2010.
QUEIROGA, R. C. F. et al. Influência de doses de nitrogênio na produtividade e qualidade do melão Cantalupensis sob ambiente protegido. Horticultura Brasileira, Brasília, v. 25, n. 4, p. 550-556, 2007.

SAEG. Sistema para Análises Estatísticas, Versão 9.1: Fundação Arthur Bernardes - UFV - Viçosa, 2007.

SAIDELLES, F. L. F. et al. Casca de arroz carbonizada como substrato para produção de mudas de tamboril-da-mata e garapeira. Semina: Ciências Agrárias, Londrina, v. 30, n. 1, p. 1173-1186, 2009.

SANTOS JÚNIOR, J. A. S. et al. Substratos e diferentes concentrações da solução nutritiva preparada em água residuária no crescimento do girassol. Revista Ciência Agronômica, Fortaleza, v. 45, n. 4, p. 696-707, 2014.

SILVA, E. F. et al. Qualidade de mudas de pepino produzidas em substratos à base de esterco ovino. Agropecuária Científica no Semiárido, Campos de Patos, v. 10, n. 3, p. 93-99, 2014.

SOUZA, E. G. F. et al. Produção de mudas de alface Babá de Verão com substratos à base de esterco ovino. Revista Caatinga, Mossoró, v. 26, n. 4, p. 63 $-68,2013$.

ZORZETO, T. Q. et al. Caracterização física de substratos para plantas. Bragantia, Campinas, v. 73, n. 3, p. $300-311,2014$. 